DOI: $10.17951 /$ lrp.2020.39.1.11-26

Monika Hajkowska

Uniwersytet Marii Curie-Skłodowskiej

ORCID - 0000-0001-5524-4246

\title{
SŁABA PŁEĆ? O NAUCZYCIELKACH DOMOWYCH W KRÓLESTWIE POLSKIM W XIX WIEKU I POCZĄTKACH XX WIEKU
}

\begin{abstract}
Streszczenie: Rozwój ruchu emancypacyjnego w XIX wieku przyczynił się do podejmowania pracy przez przedstawicielki płci pięknej. Posiadanie męża i rodziny nie zaspokajało ich potrzeb i ambicji. Redakcje czasopism kobiecych wychodziły naprzeciw oczekiwaniom kobiet, informując o potencjalnych zawodach, w których mogłyby się realizować. Praca w zawodzie nauczycielki domowej była uznawana za atrakcyjną. Jednak niewiele kobiet zdawało sobie sprawę, że jest to zawód trudny, wymagający poświęcenia. W walce o posadę rywalizowały nie tylko z kobietami, ale również z mężczyznami. Musiały zjednać sobie pracodawców i ich rodziny, zaskarbić względy uczniów. Nierzadko z uwagi na dużą ilość obowiązków odkładały plany o założeniu rodziny na później lub całkiem z nich rezygnowały, wybierając samotne życie. Niewiele z nich potrafiło łączyć pracę z obowiązkami rodzinnymi.
\end{abstract}

Słowa kluczowe: nauczycielka domowa, Królestwo Polskie, płeć, emancypacja

\section{WPROWADZENIE}

W następstwie zmian społeczno-ekonomicznych w Królestwie Polskim kobiety coraz częściej podejmowały pracę zarobkową. Determinantem zmian w spojrzeniu na rolę i miejsce kobiety w społeczeństwie był rozwijający się ruch emancypacyjny (Kowalska-Glikman 1990, s. 10-24; Nietyksza 1992, s. 139-160; Koestler 1992, s. 31-43). Przyczynił się on do tego, że przedstawicielki płci pięknej chciały być odpowiedzialne za siebie i niezależne (Goździewicz 1904a, s. 3; Goździewicz 1904b, s. 8). Dla wielu z nich rola żony i matki przestała być zadowalająca. Coraz częściej krytykowano pogląd, że rodzina i macierzyństwo jest ich jedynym powołaniem (Grudzińska 1914, s. 6; Szyc 1904, s. 27). Pracę zarobkową kobiety 
zaczęto postrzegać jako niezwykle ważny element w jej życiu, ale przede wszystkim jako podstawę jej bytu. W większości podejmowały one obowiązki zawodowe, bo zmuszała je do tego sytuacja materialna. Niekiedy bodźcem było spełnienie aspiracji zawodowych i samorealizacja, ale to należało do rzadkości. W drugiej połowie XIX wieku coraz częściej przełamywano stereotyp związany z tą stroną życia kobiet. Ze względów ekonomicznych zjawisko podejmowania przez nie pracy tłumaczono koniecznością. Ponadto w kręgach inteligencji nadawano mu znaczenie ideologiczne. Tym samym dowartościowywano kobiety, które były zmuszone podjąć pracę z przyczyn ekonomicznych. Wówczas postrzegano ich decyzję jako poświęcenie dla rodziny. W przeciwieństwie do mężczyzn ich start zawodowy był znacznie trudniejszy, a perspektywy wykonywania pracy zgodnej z ambicjami niewielkie. Należy podkreślić, że w Królestwie Polskim dziewczęta po ukończeniu pensji nie były przygotowane do pracy w żadnym z zawodów (Żarnowska 2000, s. 41-43). Dlatego doradzano im, jaki zawód powinny wybierać. Zwracano uwage na ich predyspozycje i wynikające z nich możliwości zawodowe (Walewska 1914, s. 55-68; Pachucka 1914, s. 460-461; Ilnicka 1893, s. 33-34; M.W. 1887, s. 609-612; Skrzyńska 1902, s. 122-123). W dyskusji nad rolą i zadaniami kobiety wielokrotnie podkreślano, że dorównuje w nich mężczyźnie, a nawet może z nim rywalizować (Janiszewska 1866, s. 37-39; Szyc 1904, s. 48; A.B. 1872, s. 116; Szczęsna 1887, s. 23; Orzeszkowa 1896, s. 418-419; 1897, s. 20-21). Ponadto analizowano zagadnienie opieki, którą należało otoczyć wszystkie osoby tej płci poszukujące pracy. Uświadamiano problem zagrożeń i niebezpieczeństw, na które były narażone. Pisano: „Praca zarobkowa kobiet i samodzielne tej pracy poszukiwanie do dzisiejszego dnia jeszcze posiada dwie bardzo smutne strony. Po pierwsze, jest niemiłosiernie wyzyskiwaną, znacznie więcej, niż praca mężczyzn, po drugie naraża zwłaszcza młode i niedoświadczone pracownice na tysiące pokus i niebezpieczeństw, od których przy dzisiejszym smutnym stanie moralności publicznej niezmiernie trudno przychodzi się uchronić" (J.M. 1904, s. 304).

Celem artykułu jest przedstawienie trudnej sytuacji nauczycielek domowych w Królestwie Polskim. W rozprawie podjęto próbę charakterystyki ich pracy zawodowej opartą na źródłach pamiętnikarskich, wspomnieniach. Ze względu na charakter źródeł i specyfikę badań posłużono się metodami charakterystycznymi dla nauk pedagogicznych. 


\section{WALKA O RÓWNOUPRAWNIENIE W ZAWODZIE NAUCZYCIELSKIM}

Bodźcem do podjęcia pracy przez kobiety była sytuacja materialna. Konserwatywne społeczeństwo Królestwa Polskiego nadal krytycznie oceniało takie działania wśród kobiet ze stanu szlacheckiego (ziemiańskiego) i arystokratycznego. Zjawiskiem, które obserwuje się w początkach XIX wieku, a które wpłynęło na ich aspiracje zawodowe, było rozszerzenie zakresu ich pracy i wzmocnienie pozycji w rodzinie i społeczeństwie. Kobiety pochodzenia szlacheckiego (ziemiańskiego) przejmowały część obowiązków, które do tej pory należały do służby i nauczycieli domowych. Nierzadko o ich samodzielności świadczyły prowadzone interesy związane $\mathrm{z}$ handlem i gospodarstwem. Tym samym wykonywały zadania, które były wpisane w zakres obowiązków mężczyzn. Stanowisko bardziej tolerancyjne w opinii społecznej utrzymywano wobec kobiet z rodzin mieszczańskich. Niejednokrotnie więc pracowały one przed ślubem, jak również po zawarciu związku małżeńskiego. Wynikało to z praw ekonomicznych, które przyczyniły się do zrównania kobiet i mężczyzn w obowiązkach zawodowych. Wobec czego przedstawicielki tej klasy, które były zmuszone do podjęcia pracy, spotykały się z mniejszym potępieniem ogółu (Kowalska-Glikman 1990 s. 11-14; Olszyc 1877, s. 193-194). Ruch emancypacyjny, liberalizm oraz głośne hasła pozytywizmu głoszące kult pracy wpłynęły na podejmowanie obowiązków zawodowych przez kobiety wywodzące się z inteligencji, z ziemiaństwa. W porównaniu do warstw chłopskich nie były przygotowane do wykonywania ciężkiej pracy fizycznej i przede wszystkim mniej wytrzymałe, wobec tego najczęściej podejmowały się nauczania domowego ${ }^{1}$, próbowały też swoich sił w działalności literackiej - pisarskiej (Szwarc 1992, s. 95-107). Mężczyźni zajmujący się edukacją domową, wywodzący się z różnych klas społecznych, nie byli poddawani tak krytycznej ocenie jak przedstawicielki płci żeńskiej. Wizerunek mężczyzny jako pana domu, odpowiedzialnego za jego utrzymanie, stale towarzyszył mu od najdawniejszych lat. Wobec tego podejmowanie przez nich pracy w tym zawodzie było przyjmowane przez społeczeństwo z dużą dozą tolerancji i zrozumienia.

W XIX i XX wieku przedstawicielki tej płci coraz częściej zajmowały stanowiska do tej pory zastrzeżone tylko dla mężczyzn. Jednak w walce o równouprawnienie podkreślano, aby nie zatarła się granica między płciami. W związku z tym akcentowano zgodność zawodu z tym, co zostało wpisane w ich naturę (Ilnicka 1893, s. 33). Zwolenniczką tradycyjnej roli kobiety w rodzinie i społeczeństwie była Kle-

${ }^{1}$ Nauczanie domowe -,najdawniejsza forma udzielania nauki”, A. Szycówna, 1909, Nauczanie domowe. W: J.T. Lubomirski, E. Stawiński, S. Przystański, J.K. Plebański (red.), Encyklopedya Wychowawcza. Warszawa, skł. gł. Księg. Gebethner i Wolff, t. 7, s. 530. 
mentyna z Tańskich Hoffmanowa. Sprzeciwiała się nowoczesnym dążeniom kobiet. Według niej ich działania przyczyniały się do negatywnej zmiany wizerunku płci pięknej (Tańska 1876, s. 310-314). Konserwatywny w tych poglądach był również Henryk Wernic (1958, s. 16-18) oraz Bronisław Trentowski (1899, s. 57-58). Zupełnie odmienne zdanie w kwestii emancypacji kobiet miał Henryk Struve. Pisał „Kobieta i mężczyzna, z natury swojej, mają zupełnie różne zadanie i stanowisko $\mathrm{w}$ życiu familijnem, $\mathrm{w}$ domu, a to pociąga za sobą taką zasadniczą różność oboich płci i w życiu publicznem, w społeczeństwie i państwie, że w normalnym stanie tych ostatnich, nigdy mowy być nie może o ich zupełnem zrównaniu" (1867, s. 50).

Zawód nauczycielki domowej zaliczał się do najbardziej popularnych wśród kobiet. W drugiej połowie XX wieku jak pisała Romana Pachucka w ich deklaracjach najczęściej pojawiało się „będę nauczycielką! - najłatwiejsze rozwiązanie kwestyi” (1914, s. 461). Szanse wykonywania tego zawodu były dla nich najbardziej realne. Spełnienie wymagań, to jest posiadanie odpowiedniego wykształcenia, kwalifikacji, patentu nauczycielskiego, dla kobiet $\mathrm{z}$ rodzin ziemiańskich, inteligenckich, a nawet mieszczańskich stanowiło cel możliwy do osiągnięcia (Żarnowska 2000, s. 31). Według opinii Elizy Orzeszkowej zawód ten stanowił „uniwersalny środek na każdą biedę, na każde zubożenie kobiety" (1873, s. 169-170). Z kolei Feliksa Eger określała je jako „najszczytniejsze z powołań...” (1874, s. 191).

Aprobata i przyzwolenie społeczne były ważnymi czynnikami, warunkującymi dostęp do tego zawodu. Cieszył się on wysokim stopniem tolerancji. Wizerunek nauczycielki był zbliżony do ideału żony, matki. Zawód ten wymagał od kobiety tych samych lub podobnych cech niezbędnych do pełnienia tych funkcji, jak również zgodnych z jej tradycyjnym wzorcem. To wszystko czyniło go atrakcyjnym wśród przedstawicielek płci pięknej i w dużej mierze decydowało o jego wyborze. Kobiety, które decydowały się na wykonywanie tego zawodu, sugerowały się opinią publiczną, czasem pracy i odpoczynku oraz jego dostępnością (Niklewska 1992, s. 268; Caban 1992, s. 263-264). Jednak pomimo dużego zainteresowania w kręgach kobiet zawodem nauczycielki to w rywalizacji z mężczyznami zawsze zajmowały one niższą pozycję. Z tym prymatem mężczyzn nie zgadzało się wiele kobiet. Wspomniana już Eliza Orzeszkowa wyrażała $z$ tego powodu swoje niezadowolenie, pisząc: „Mężczyzna nauczyciel, jak guwernantka ${ }^{2}$ cudzoziemka, uważany jest za rodzaj zaszczytu dla domu i uświetnienia edukacji dzieci” (1873, s. 180). Nauczyciele płci męskiej byli faworyzowani przez przełożonych pensji, rodziców. Zapraszano ich na rozmowy, proponowano podjęcie się obowiązków zawodowych. Tymczasem kobiety same

${ }^{2}$ Guwernantka - „kobieta, której poruczają wychowanie dzieci, nauczycielka”, Słownik języka polskiego. Wypracowany przez A. Zdanowicza, M. Bachuna Szynkę, J. Filipowicza, W. Tomaszewicza, F. Czepielińskiego i W. Korotyńskiego, z udziałem B. Trentowskiego. 1861, Wilno, M. Orgelbrand, cz. 1, s. 38 . 
musiały starać się o posadę i cierpliwie czekać na decyzję pracodawców o ich zatrudnieniu. Dlatego apelowano o równe szanse w tym zawodzie. Eliza Orzeszkowa uważała, że w wyborze osoby nauczyciela powinny decydować jego zdolności, a nie płeć. Obalała zarzuty pod adresem kobiet dotyczące ich kwalifikacji i kompetencji (1873, s. 181-183). Problem dyskryminacji kobiet w zawodzie nauczycielskim znany był także Anieli Szycównie, nauczycielce domowej z patentem wyższym. Uważała ona, że przedstawicielkom płci pięknej powierza się z reguły małe dzieci i zadania mniej odpowiedzialne niż mężczyznom. Stawała w obronie nauczycielek, podkreślając ich predyspozycje cenne w tym zawodzie, takie jak cierpliwość, opiekuńczość. Ponadto twierdziła, że wychowanie od zawsze kojarzyło się z kobietą, a nie z mężczyzną (1908, s. 7-9). Z kolei Romana Pachucka podkreślała, że w tym zawodzie jest miejsce dla wszystkich, którzy będą do niego przygotowani. Dodatkowo analizując sytuację oświaty i szkolnictwa, zwracała uwagę na to, że w tej dziedzinie otwierają się nowe możliwości. Wobec czego radziła, aby rozsądnie planować swoją przyszłość, a w realizacji swych celów nie szczędzić pracy i wysiłku (1914, s. 463). Krytycznie oceniane były osoby, które trafiały do tego zawodu przypadkowo bądź podejmowały się go z braku innych możliwości. Dlatego podkreślano, aby wybór tego zawodu był przemyślany i zawsze podyktowany rozwagą. Pisano: „Nie zawód zdobi człowieka, lecz człowiek zdobi zawód” (Rogożewski 1914, s. 457-458).

\section{WYKSZTAŁCENIE I KWALIFIKACJE PEDAGOGICZNE}

Pracodawcy wymagali od nauczycielek odpowiedniego wykształcenia, które byłoby gwarancją ich przygotowania do podjęcia się obowiązków zawodowych. Na podstawie analizy pamiętników można stwierdzić, że przeważały osoby ze średnim wykształceniem. Zdarzały się niezwykle ambitne nauczycielki domowe, które wykształceniem dorównywały mężczyznom. Zofia Stokowska, nauczycielka Henryka Wiercieńskiego, była wychowanką Instytutu Panien Szlacheckich w Puławach (Wiercieński 1974, s. 66). Podobnie było z Michaliną Mostowską, zaangażowaną przez rodzinę Grodzickich. Ukończyła seminarium nauczycielskie oraz studiowała w Konserwatorium Muzycznym w Krakowie (Grodzicka 1999, s. 91). Natalia Baszkatow, guwernantka, była absolwentką instytutu naukowego w Petersburgu (APL, GWL, sygn. 516. Świadectwo wydane przez Kuratora ONW z dn. 16 maja 1845 roku). Konstancja Oxińska, pozostająca w rodzinie Jezierskiego oraz Maria Remiszewska kształciły się Instytucie Aleksandryjskim (APL, GWL, sygn. 521, sygn. 509). Guwernantki, Joanna Chrapczyńska oraz Paulina Ladachowska, kształciły się w Lublinie. Pierwsza ukończyła Szkołę Wyższą Płci Żeńskiej ss. Wizytek w Lublinie, a druga pensję wyższą (APL, GWL sygn. 512, s. 79-80, 105). 
Wśród kobiet ze średnim wykształceniem były również osoby, które wyróżniały się bardzo wszechstronną wiedzą. Taką była p. Okolska, nauczycielka domowa Janiny Porazińskiej, absolwentka szkoły klasztornej. Zdobyła ją dzięki wytężonej, samodzielnej pracy, której sprzyjały jej zdolności, między innymi bardzo dobra pamięć. „W rozprawy z zakresu historii, tak polskiej jak i powszechnej - wspomina jej uczennica - lepiej było z nią się nie wdawać, bo każdego zapędziła w kozi róg" (Porazińska 1988, s. 149-150). Szkołę średnią ukończyły również Maria Pajewska i Wiera Kozaczkowska („Cirkular po Warszawskomu Uczebnomu Okrugu”, 1898, nr 1, s. 38; nr 10, s. 288). Z kolei Emilia Sukertowa-Biedrawina legitymująca się świadectwem nauczycielki domowej ukończyła pensję prywatną w Warszawie (Sukertowa-Biedrawina 1965, s. 12). Wykształcenie średnie uzyskała Maria Konopnicka, podejmująca się obowiązków w charakterze nauczycielki domowej. Zdobyła je, ucząc się w domu rodzinnym i na pensji (Baculewski 1967-1968, s. 576). Również w domu rodzinnym kształciły się nauczycielki domowe, Waleria Hirner (APL, GWL, sygn. 512, s. 194-198) i Klara Miłoszewska (APL, GWL, sygn. 510, s. 189) oraz guwernantki, Zuzanna Gumińska (APL, GWL, sygn. 516. Świadectwo wydane przez Kuratora ONW z dn. 1 czerwca 1844 roku) i Emilia Płużańska (APL, GWL, sygn. 516. Świadectwo wydane przez Kuratora ONW z dn. 30 listopada $1843 \mathrm{roku})$. Bona ${ }^{3}$, Rozalia Zake, z pochodzenia Szwajcarka, uczyła się na pensji (APL, GWL, sygn. 562. Wykaz imienny guwernerów i nauczycieli prywatnych w guberni lubelskiej za rok 1841/1842).

Nauczycielki domowe nierzadko wykorzystywały nowoczesne metody nauczania oraz sięgały po różnorodne pomoce naukowe. Szczególnie polecaną metodą nauczania w okresie przedszkolnym była metoda wzorowana na freblowskiej. Uświadamiano zarówno rodziców, jak i nauczycieli domowych, aby poznali i wykorzystywali tę metodę w edukacji domowej (Z pedagogiki 1868, s. 58). Dzięki zajęciom freblowskim dzieci szybciej rozwijały się umysłowo. Ćwiczenia można było prowadzić zarówno na świeżym powietrzu, jak i w domu. Bardzo przydatne były także odpowiednie zabawki, które wspomagały ich rozwój. Rodzice doceniali metody freblowskie w nauczaniu domowym swoich dzieci, dlatego poszukiwali wykształconych nauczycielek. Władysław Tatarkiewicz wspomina, że były one wykorzystywane w procesie jego edukacji przez nauczycielkę. Szczególnie zapamiętał zajęcia, na których lepił różne rzeczy z plasteliny (Tatarkiewiczowie 1979, s. 121). Helena Elschewitz, bona Jadwigi Waydel-Dmochowskiej, również wykorzystywała te metody (Waydel-Dmochowska, 1958, s. 121).

${ }^{3}$ Bona - „dozorczyni dzieci, niańka dość ukształcona”, Słownik języka polskiego. Wypracowany przez A. Zdanowicza, M. Bachuna Szynkę, J. Filipowicza, W. Tomaszewicza, F. Czepielińskiego i W. Korotyńskiego, z udziałem B. Trentowskiego. 1861, Wilno, M. Orgelbrand, cz. 1, s. 98. 
Wspomnienia z nauki początkowej pod kierunkiem bony zachował Karol Mitkiewicz. Uczyła go języka niemieckiego przez konwersację. Dzięki niej opanował niektóre piosenki w tym języku. Chodziła z nim na spacery oraz towarzyszyła mu podczas zajęć gimnastyki (Mitkiewicz 1970, s. 6). Na konwersacji oparta była nauka języka francuskiego prowadzona przez bonę Artura Rubinsteina (Sukertowa-Biedrawina 1965, s. 8). Podobnie jak lekcje Francine Lallmend, bony Antoniego Kieniewicza. W nauce języka francuskiego wykorzystywała ona bajki oraz doskonaliła znajomość tego przedmiotu podczas rozmów na spacerach i na spotkaniach towarzyskich (Kieniewicz 1989, s. 46-47).

W rodzinie Augusta Iwańskiego Teresa Kalinowska, nauczycielka domowa, sięgała po odpowiednie książki i podręczniki. Była odpowiedzialna za nauczanie początkowe, uczyła czytania, pisania, arytmetyki, w tym czterech działań, a także dziejów biblijnych, historii Polski i gry na fortepianie. Na przykład na prowadzonych przez nią lekcjach historii czytano i analizowano takie pozycje, jak Pielgrzym $z$ Dobromilu Izabeli z Flemingów Czartoryskiej, Śpiewy historyczne Juliana Ursyna Niemcewicza (Iwański 1968, s. 40). Z kolei nauczycielka Izabeli Stachowicz stosowała w nauce przedmiotów przyrodniczych metodę poglądowości. Przynosiła na lekcje eksponaty zwierząt, które nie zawsze spotykały się z zadowoleniem uczennicy (Stachowicz 1958, s. 67). Jedna z nauczycielek domowych wspomina: „Książki nie potrzebujemy żadnej, uczymy się na wszystkiem co nas otacza” (Listy z praktyki nauczycielskiej 1875, s. 456). Inaczej było w domu Teodora Kaczyńskiego, który pobierał lekcje od Pani Grzybek. Jego nauczycielka domowa nie tylko sięgała do pozycji szkolnych, ale również prenumerowała czasopisma, których artykuły dostarczały im ciekawych tematów do dyskusji (Kaczyński 1987, s. 55).

\section{PODEJŚCIE DO OBOWIĄZKÓW ZAWODOWYCH, SYTUACJA BYTOWA}

Wśród nauczycielek domowych było wiele osób, które obowiązki wykonywały bardzo rzetelnie, a w pracę wkładały cały swój wysiłek i poświęcenie. Profesjonalizm nauczycielki umożliwiał jej utrzymanie się w zawodzie. Krytykowano cudzoziemki, które podejmowały się edukacji, nie mając żadnego przygotowania, a jedynie posiadały znajomość języka (Szycówna 1915, s. 22). Autorzy pamiętników wspominają o nauczycielkach domowych, które cieszyły się dużym uznaniem i bardzo dokładnie realizowały powierzone im przez pracodawców zadania. W rodzinie Kazimierza Jaworskiego szczególnie zapamiętano Polkę Romanę Zapasiewicz, która nie tylko wiedzą, ale i podejściem do obowiązków zawodowych zaskarbiła sobie ich względy. W rywalizacji z nauczycielami obcego pochodzenia okazała się bezkonkurencyjna (Jaworski 1968, s. 37). Selektywnie dobierano nauczyciel- 
ki cudzoziemki w rodzinie Marii Kleniewskiej. Wspaniałą postacią okazała się sprowadzona z Wrocławia Niemka o nazwisku Schreiber (Kleniewska 2002, s. 18). O starannym wychowaniu matki pod okiem Francuzki pisał również Stanisław Arct (1962, s. 38).

Do obowiązków nauczycielek domowych należało nie tylko wychowanie, edukacja i opieka nad dzieckiem. Pracodawcy zlecali im dodatkowe zajęcia związane $\mathrm{z}$ gospodarstwem domowym, takie jak szycie, gotowanie, sprzątanie, prowadzenie administracji (Nauczycielka 1896, s. 143-144). Zdarzały się sytuacje, że czas ich pracy wynosił dziewięć godzin lub nawet więcej (J.M. 1886, s. 41; Hajkowska 2009, s. 134).

Problem przeciążenia nauczycielek domowych był podejmowany na łamach prasy. Uświadamiano zagrożenia, z jakimi wiąże się wykonywanie zawodu nauczycielki domowej. Twierdzono, że przemęczenie może prowadzić do utraty zdrowia, nie tylko fizycznego, ale również psychicznego. Kobiety zmuszone ze względów materialnych przyjmować każdą proponowaną im posadę nauczycielki domowej oraz godzić się na mierne warunki pracy popadały często w stan rozgoryczenia, czuły się wykorzystywane. W efekcie prowadziło to załamania bądź innych poważniejszych chorób nerwowych (W.H. 1895, s. 182). Winą za przeciążenie w pracy pedagogicznej obarczano także same nauczycielki domowe. Przyczyn ich stanu doszukiwano się w ich nadmiernej ambicji i sumienności. W wykonanie swoich zadań często wkładały całą swoją energię, serce i duszę, a to kończyło się ubytkiem zdrowia. Poza tym podejmowały zbyt wiele obowiązków, niewspółmiernie do swoich możliwości, a to także mogło być zgubne w skutkach. W związku z tym radzono im, aby nie popełniały tych błędów i w pracy kierowały się rozsądkiem oraz troską o własne zdrowie. Bardzo dobrym rozwiązaniem było właściwe planowanie czasu pracy. Apelowano o higienę umysłu, a z nią o racjonalne odżywianie, konieczną ilość snu oraz o ruch na świeżym powietrzu. Szczególnie ważne w kwestii zdrowia było wykonywanie badań lekarskich, które potwierdziłyby dobry stan zdrowia osób chcących zajmować się zawodem nauczycielskim. Twierdzono, że wynik stwierdzający jakieś nieprawidłowości powinien stanowić przeszkodę w podjęciu tej pracy (Garczyńska 1896, s. 144).

Kobiety w zawodzie nauczycielskim zarabiały dużo mniej od mężczyzn podejmujących się tego zajęcia. Nauczycielki zatrudnione na stałe w domu pracodawców mogły uzyskać do 400 rubli rocznie, rzadko więcej. Natomiast ceniony nauczyciel domowy otrzymywał oferty sięgające do nawet 1000 rubli (Ogłoszenia 1895, nr 7, s. 100; 1895, nr 1, s. 8.; Młoda Nauczycielka 1888, s. 117-118; Hajkowska 2009, s. 135). Utrzymanie przy tak niskich zarobkach wymagało wielu wyrzeczeń. Jedna z nauczycielek, która nauczaniem domowym zajmowała się od siedemnastu lat, zaznaczała, że musiała się nauczyć oszczędności. Połowę swych rocznych dochodów 
w wysokości 300 rubli przeznaczała na spłatę długów, z pozostałych pieniędzy zaś tylko niewielką część wykorzystywała na swoje potrzeby. Garderobę jej od kilku lat stanowiła jedna czarna suknia (Słowo prawdy. Do moich towarzyszek 1884, s. 203). W przypadku osób, które z zarobionych pieniędzy utrzymywały nie tylko siebie, ale również swoją rodzinę sytuacja przedstawiała się znacznie poważniej. Pokazuje to historia jednej z młodych nauczycielek, która po ukończeniu pensji podjęła się nauczania domowego. Jej wynagrodzenie miesięczne stanowiło zaledwie 35 rubli miesięcznie, za co utrzymywała matkę i siostrę. Praca zajmowała jej cały dzień. Obiady jadała dopiero wieczorem po lekcjach. W najlepszej sytuacji wystarczało na mięso dwa razy w tygodniu, ale bywało i tak, że posiłek stanowił suchy chleb, kasza na wodzie i herbata (Czesława 1900, s. 284)

Niekiedy nauczyciele domowi podejmowali obowiązki w zamian za mieszkanie i wyżywienie. Dzięki takiemu rozwiązaniu nie musieli ograniczać się w zatrudnieniu do jednej rodziny. Wówczas mogli kilka godzin w ciągu dnia zajmować się dziećmi pracodawców, u których mieszkali, a pozostały czas wykorzystywali na udzielanie lekcji u innych („Kurier Warszawski” 1851, nr 30, s. 155; nr 177, s. 944; nr 263, s. 1388). Jednak bywali i tacy, dla których taka forma zapłaty stanowiła jedyne wynagrodzenie. Zmuszała ich do tego trudna sytuacja materialna, dlatego dach nad głową i pożywienie były dla nich wystarczające („Kurier Warszawski” 1849, nr 186, s. 920). Wśród nich byli tacy, którzy posiadali pewne fundusze finansowe zgromadzone wcześniej, więc mogli sobie pozwolić na przyjęcie takiej oferty. Pieniądze te bowiem pozwalały im na zakup wszystkich najbardziej niezbędnych do życia rzeczy. Czytamy w jednym z ogłoszeń: „Osoba w średnim wieku, własne mająca fundusze, pragnie umieścić się w domu, gdzie są małe dzieci, któreby mogła dozorować, udzielać początków nauk nie żądając żadnej pensji oprócz stołu i stancyi” („Kurier Warszawski” 1849, nr 301, s. 1594).

Najgorsza była sytuacja bytowa nauczycielek dochodzących, które zajmowały się udzielaniem lekcji na godziny, najczęściej kolejno w kilku domach. Taka praca wiązała się z wysiłkiem nie tylko intelektualnym, ale także fizycznym. Nauczycielki te były zmuszone pokonywać często duże odległości dzielące domy ich pracodawców. Złe warunki atmosferyczne okazywały się nie lada przeszkodą, a do tego dochodziło zmęczenie i niedożywienie (Garczyńska 1896, s. 103). W porównaniu z nimi w lepszej sytuacji znajdowały się nauczycielki stałe, które na czas nauki przenosiły się do domu ucznia.

Problemem trudnym do rozwiązania przez nauczycieli i nauczycielki domowe było odliczanie przez pracodawców dni świątecznych, wakacji. Nie zawsze rodziny decydowały się na wyjazd z nauczycielką bądź nauczycielem. Wówczas osoby zajmujące się nauczaniem domowym traciły część dochodów. Obraz takiej sytuacji został przedstawiony na łamach czasopisma „Dziecko”. Chlebodawczyni 
poinformowała nauczycielkę o planowanym wyjeździe rodziny, co w konsekwencji wiązało się także z przerwaniem lekcji na pewien czas. Dla nauczycielki był to prawdziwy powód do zmartwień, ponieważ podróż ustalono na 15 maja, a podjęcie ponownych lekcji było możliwe dopiero 1 listopada (Tyszkówna 1914, s. 398). Autorka podkreślała trudne położenie nauczycielek domowych, „Wolny najmita! Ciągle poszukujący pracy, ciągle niepewny jutra, ciągle zależny od dobrej woli pracodawców - czyż może dobrze spełniać swe zadanie? Czy może oddać się duszą całą uczennicy jeżeli po nocach trapią go zmory przymusowej głodówki, widma «wolności» bez dachu" (Tyszkówna 1914, s. 398-399).

Sytuację bytową zarówno nauczycieli, jak i nauczycielek domowych pogarszały także nieregularne wypłaty należności dokonywane przez pracodawców. Często zdarzały się przypadki, kiedy rodzice zwlekali z wypłatą ich wynagrodzenia. Niekiedy posuwali się do tego, aby jak najdłużej odwlekać termin jego zapłaty. Nierzadko więc zamiast rozliczyć się z oczekującym na ten moment nauczycielem wyjeżdżali w podróż lub byli dla niego nieobecni (K.L. 1898, s. 54). Takie zachowania były podyktowane lekkomyślnością, złośliwością i przede wszystkim skąpstwem.

Autorka ukrywająca się za inicjałami J.K. także zwracała uwagę na wykorzystywanie finansowe osób zajmujących się nauczaniem domowym. Według niej absurdalne i nie do przyjęcia były propozycje wynagrodzenia ze strony pracodawców za „świeże powietrze i życie na wsi” (J.K. 1895, s. 215). Poniekąd winą za obniżanie wynagrodzenia obarczała również nauczycielki domowe, które w obliczu dużej konkurencji same proponowały bądź godziły się na bardzo niskie opłaty za godziny lekcji (Czesława 1900, s. 277-279.)

\section{REZYDENTKI}

Zmiana miejsca pracy stanowiła wyzwanie dla wielu nauczycielek domowych. Przenoszenie się z jednej do drugiej rodziny bywało uciążliwe zarówno pod względem fizycznym, jak i emocjonalnym oraz psychicznym. Wiele zależało od angażujących pracodawców, którzy najczęściej z góry określali, na jaki okres czasu zatrudnią nauczycieli w swoich domach. Zdarzały się sytuacje, kiedy osoby zajmujące się edukacją domową przedłużały swój pobyt u angażujących je rodzin. Należały do nich przede wszystkim osoby określane jako rezydentki ${ }^{4}$.

${ }^{4}$ Rezydent - „bezdomny przyjaciel, weteran, wysłużony oficjalista lub biedny daleki krewny, rezydujący stale w bogatym domu, dworzanin respektowy”. Rezydentka - „forma żeńska od rezydent”. W. Niedźwiedzki 1909, Słownik języka polskiego. Z udziałem K. Króla. Warszawa, nakł. prenumeratorów i kasy im. Mianowskiego, t. 5, 528. 
Problem zarówno rezydentów, jak i rezydentek był dość wstydliwy. Mieszkanie kątem u rodziny, bez środków do życia nie było powodem do chluby. Niewiele osób zajmujących się nauczaniem domowym przyznawało się do tego z obawy przed ośmieszeniem. Ich ukorzenienie pogłębiała zależność od krewnych bądź dawnych pracodawców.

Rezydentkami zostawały najczęściej kobiety zajmujące się nauczaniem domowym, rzadziej mężczyźni. Dochodziło do takich sytuacji wtedy, gdy nauczycielka domowa nawiązywała $\mathrm{z}$ rodziną bardzo bliskie relacje i stawała się formalnie jej członkiem. Pomimo tego, że zakończyła edukację powierzonych jej dzieci pozostawała nadal w domu ich rodziców. Powierzano jej wówczas inne zadania i obowiązki niż dotychczasowe. Często była damą do towarzystwa matki uczennic lub osobą sprawującą opiekę nad innymi członkami rodziny. W zamian za pracę otrzymywała pokój, pożywienie, uczestniczyła aktywnie w życiu towarzyskim domowników (Orzeszkowa 1948, s. 32). W tej roli pracowały kobiety spokrewnione z pracodawcami lub „stare panny” (Prus 1957, s. 75-76). Zwyczaj angażowania rezydentek był praktykowany najczęściej w rodzinach, których sytuacja finansowa pozwalała im na ponoszenie stałych wydatków związanych $\mathrm{z}$ ich utrzymaniem. Bronisław Kopczyński wspomina w pamiętnikach, że w jego rodzinie stale przebywała rezydentka (Kopczyński 1959, s. 30). O takich rezydentkach wspominała również Krystyna Okołowiczowa. Określała je jako nauczycielki-przyjaciółki. Były to osoby, które pozostawały u zatrudniającej je rodziny nawet do końca życia. Kobiety te zżywały się z jej domownikami, towarzyszyły im w trudnych sytuacjach życiowych, stawały się powierniczkami ich tajemnic, a niekiedy podejmowały się obowiązków służących, pokojówek, a nawet kucharek (Okołowiczowa 1896, s. 410). W takim charakterze pracowała panna Wybranowska, guwernantka Anieli i Leokadii Koczorowskich. Oprócz obowiązków związanych z edukacją domową zajmowała się gospodarstwem $w$ ich domu. Musiała słono zapłacić za dożywotni dach nad głową, posiłek i niskie wynagrodzenie. Doznawała przykrości i upokorzeń ze strony domowników, nie była traktowana $\mathrm{z}$ należytym szacunkiem (Rogowska 2000, s. 24).

Wobec krzywdzących opinii o rezydentkach i rezydentach nie wszystkie nauczycielki domowe decydowały się na pracę $\mathrm{w}$ domach prywatnych $\mathrm{w}$ takim charakterze. Propozycję posady rezydentki otrzymała od swoich krewnych Zofia Bouffałowa, wdowa po zmarłym Hipolicie Bouffale. Była osobą o silnym charakterze i niezwykle ceniącą sobie własną samodzielność, dlatego oferty tej nie przyjęła. Zgodziła się natomiast pracować $\mathrm{w}$ charakterze honorowej guwernantki w ich domu oraz damy do towarzystwa dla matki swojej uczennicy (Wawrzykowa-Wierciochowa 1975, s. 9-10). 


\section{PODSUMOWANIE}

Kobiety podejmujące obowiązki zawodowe w zawodzie nauczycielskim musiały się liczyć się z tym, że w konkurencji z mężczyznami będą zajmowały drugą pozycję. Walka o równouprawnienie i niezależność finansową nie należała do łatwych. Nauczycielki domowe musiały posiadać odpowiednie wykształcenie i kwalifikacje zawodowe, wykazać się profesjonalizmem przed potencjalnym pracodawcą. Nierzadko walczyły ze stereotypami w spojrzeniu na rolę i miejsce kobiety w społeczeństwie. Zdarzały się sytuacje, kiedy były upokarzane i wykorzystywane przez członków angażujących je rodzin. Niekiedy nie były świadome, że wybór kariery zawodowej może przekreślić ich szansę na wstąpienie w związek małżeński oraz posiadanie potomstwa. Musiały udowadniać, że w walce o swoje cele zawodowe wykażą się siłą i determinacją.

\section{LITERATURA}

„Cirkular po Warszawskomu Uczebnomu Okrugu”, 1898, nr 1,38; nr 10, 288.

„Kurier Warszawski” 1849, nr186, 920; nr 301, 1594; 1851, nr 30, 155; nr 177, 944; nr 263, 1388.

„Przegląd Pedagogiczny” 1888, nr 5, 60; 1895, nr 14, 215; 1898, nr 4, 52.

APL, GWL, sygn. 509. Pismo S. Czernickiego z dn. 31 grudnia 1847 r.

APL, GWL, sygn, 510, sygn. 512.

APL, GWL, sygn. 516. Świadectwo wydane przez Kuratora ONW z dn. 1 czerwca 1844 r. APL, GWL, sygn. 516. Świadectwo wydane przez Kuratora ONW z dn. 16 maja 1845 r. APL, GWL, sygn. 521. Świadectwo wydane przez Kuratora ONW z dn. 7 marca 1844 r., APL, GWL, sygn. 562. Wykaz imienny guwernerów i nauczycieli prywatnych w guberni lubelskiej za rok 1841/42.

Arct A., 1962, Okruchy wspomnień. Warszawa Państwowy Instytut Wydawniczy 1962. B.A., 1872, Wiadomości literackie. Kilka myśli o wychowaniu i wykształceniu niewiast naszych przez Dzieduszycka A. „Kronika Rodzinna”, nr 8, 115-117.

Baculewski J., 1968, Konopnicka Maria. W: E. Rostworowski (red.), Polski słownik biograficzny. T. 13. Wrocław - Warszawa - Kraków, Zakład Narodowy im. Ossolińskich - Wydawnictwo Polskiej Akademii Nauk, 576.

Caban W., 1992, Nauczycielki w szkołach elementarnych $w$ Królestwie Polskim w pierwszej połowie XIX wieku. W: A. Żarnowska, A. Szwarc (red.), Kobieta i edukacja na ziemiach polskich w XIX i XX w. Zbiór studiów. T. 2, cz. 1. Warszawa, Instytut Historyczny Uniwersytetu Warszawskiego, 257-265.

Czesława M., 1900, Z życia nauczycielki. „Bluszcz”, nr 36, 284. 
Eger E., 1874, Słówko o obowiązkach rodziców i nauczycielek w prowadzeniu dzieci. „Kronika Rodzinna”, nr 12, 191-200.

Garczyńska M., 1896, W kwestii położenia nauczycielek. „Przegląd Pedagogiczny”, nr 6, 103.

Goździewicz J., 1904a, Kwestya kobieca ze stanowiska społeczno - etycznego. Poznań, nakł. i dr. Druk. i Księg. św. Wojciecha.

Goździewicz J.1904b, O emancypacyi zarobkowej kobiet. Poznań, nakł. i dr. Druk. i Księg. św. Wojciecha.

Grodzicka M., 1999, Wśród polskich pól przed laty. wspomnienia. Włocławek, „Lega”. Grudzińska A., 1914, O powołaniu kobiety. W: A. Szycówna (red.), Dziewcze polskie. Książka zbiorowa dla dorastających panien. Warszawa, E. Wende.

Hajkowska M., 2009, Zatrudnienie, praca i warunki bytowe nauczycieli domowych w Królestwie Polskim. W: S. Popek, A. Winiarz (red.), Nauczyciel. Zawód. Powołanie. Pasja. Lublin, Wydawnictwo Uniwersytetu Marii Curie- Skłodowskiej, s. 126-140. Ilnicka M., 1893, Zarobkowa praca kobiety. „Bluszcz”, nr 5, 33-34.

Iwański A. (senior), 1968, Pamiętniki 1832-1876. W: A. Iwański (junior). Wspomnienia 1881-1939. Słowo wstępne J. Iwaszkiewicz, opracował W. Zawadzki. Warszawa, Państwowy Instytut Wydawniczy.

Janiszewska J., 1866, Kobieta na katedrze. „Kółko Domowe”, z. 6, 37-39.

Jaworski K., 1968, Wywoływanie cieni. Lublin, Wydawnictwo Lubelskie.

J.K., 1895, Kilka słów o materialnem położeniu nauczycielek. „Przegląd Pedagogiczny", nr 14, 215.

J.M., 1886, Położenie nauczycielek. „Przegląd Pedagogiczny”, nr 3, 41.

J.M., 1904, Opieka nad kobietami poszukującymi pracy u nas i na zachodzie. W: Kobieta współczesna. Książka zbiorowa. Nakład tygodnika „Bluszcz”. Warszawa skł. gł. w Księgarni Gebethnera i Wolffa, 304-315.

Kaczyński T., 1987, Z żółtym kuferkiem. Wspomnienia ludowca i nauczyciela. Warszawa, Ludowa Spółdzielnia Wydawnicza.

Kieniewicz A., 1989, Nad Prypecią, dawno temu. Wspomnienia zamierzchłej przeszłości. Wrocław-Warszawa-Kraków-Gdańsk-Łódź, Zakład Narodowy im. Ossolińskich. Kleniewska M., 2002, Wspomnienia. Redakcja i opracowanie tekstu. W. Włodarczyk. Wilków, Regionalne Towarzystwo Powiślan.

Koestler N., 1992, Kobiety polskie między społeczeństwem tradycyjnym a nowoczesnym. W: Żarnowska, A. Szwarc (red.), Kobieta i edukacja na ziemiach polskich w XIX i XX w. Zbiór studiów. T. 2. , cz. 1,Warszawa, Instytut Historyczny Uniwersytetu Warszawskiego, 31-43.

Kopczyński B., 1959, Przy lampce naftowej . wspomnienia o dawnej Warszawie, Krakowie, wędrówkach z farbami, spotkanych ludziach 1882-1952. Warszawa, Czytelnik. 
Kowalska-Glikman S., 1990, Kobiety $w$ procesie przemian społecznych $w$ Królestwie Polskim w XIX wieku. W: A. Żarnowska, A. Szwarc (red.), Kobieta i społeczeństwo na ziemiach polskich $w$ XIX w. Zbiór studiów. Warszawa, Instytut Historyczny Uniwersytetu Warszawskiego, 10-24.

K.L., 1898, Dola i niedola nauczycieli szkół prywatnych. „Przegląd Pedagogiczny”, nr 5, 53-54.

Listy z praktyki nauczycielskiej, 1875, „Opiekun Domowy”, nr 29, 455- 456.

M.W., 1887, Pewne drogi pracy dla kobiet. „Kronika Rodzinna”, nr 20, 609-612.

Mitkiewicz K., 1970, Spojrzenie wstecz. Warszawa, Czytelnik.

Młoda Nauczycielka, 1888, Głosy wychowawców. Francuzo - i muzykomanija. „Przegląd Pedagogiczny", nr 10, 117-118.

Nauczycielka, 1896, O położeniu nauczycielek. „Przegląd Pedagogiczny”, nr 8, s. 143-144.

Niedźwiedzki W., 1909, Słownik języka polskiego. Z udziałem K. Króla. T. 5. Warszawa, nakł. prenumeratorów i kasy im. Mianowskiego.

Nietyksza M., 1990, Przemiany aktywności zawodowej kobiet. Warszawa na przełomie XIX i XX wieku. W: A. Żarnowska, A. Szwarc (red.), Kobieta i społeczeństwo na ziemiach polskich $w$ XIX w. Zbiór studiów. Warszawa, Instytut Historyczny Uniwersytetu Warszawskiego, 139-160.

Niklewska J., 1992, Być kobietą pracująca - czyli dola warszawskiej nauczycielki na przełomie XIX i XX wieku. W: A. Żarnowska, A. Szwarc (red.), Kobieta i edukacja na ziemiach polskich wXIX i XX w. Zbiór studiów. T. 2. Cz.1. Warszawa, Instytut Historyczny Uniwersytetu Warszawskiego, 267-280.

Ogłoszenia, 1895, „Przegląd Pedagogiczny”, nr 1, 8; nr 7, 100.

Olszyc J. dr, 1877, Proletaryat kobiecy. II. Stosunki ekonomiczne dawniejsze i obecne. „Kronika Rodzinna”, 1877, nr 13, 193-194.

Orzeszkowa E., 1873, Kilka słów o kobietach. Warszawa, S. Lewental.

Orzeszkowa E., 1896, W kwestyi równouprawnienia kobiet wobec nauki, pracy i dostojności ludzkiej (List otwarty do kobiet niemieckich). „Bluszcz”, 1896, nr 53, 418-419.

Orzeszkowa E., 1897, W kwestyi równouprawnienia kobiet wobec nauki, pracy i dostojności ludzkiej (List otwarty do kobiet niemieckich). „Bluszcz”, nr 3, 20-21.

Orzeszkowa E., 1948, Nad Niemnem. T. 1. Warszawa Gebethner i Wolff.

Pachucka R., 1914, Wybór zawodu i nauczycielstwa. „Dziecko”, z. 8/9, 460-461.

Porazińska J., 1988, I w sto koni nie dogoni. Gawęda o moim dzieciństwie. Warszawa, Czytelnik.

Prus, B., 1957, Kroniki. T. 6. Opracował Z. Szweykowski. Warszawa: Państwowy Instytut Wydawniczy.

Rogowska P.K., 2000, Pamiętnik warszawskiej pensjonarki. Warszawa: „DiG”.

Rogożewski R., 1914, Wybór zawodu. „Dziecko”, 1914, z. 8/9, 457-458. 
Skrzyńska K., 1902, Co robić z sobą. Praca zawodowa kobiet. „Tygodnik Ilustrowany”, nr 7, 122-123.

Słownik języka polskiego, 1861, wypracowany przez A. Zdanowicza, M. Bachuna Szynkę, J. Filipowicza, W. Tomaszewicza, F. Czepielińskiego i W. Korotyńskiego, z udziałem B. Trentowskiego, cz. 1. Wilno, M. Orgelbrand.

Słowo prawdy. Do moich towarzyszek, 1884, „Biesiada Literacka”, nr 430, 203.

Stachowicz I. (Czajka), 1958, Córka czarownicy na huśtawce. Warszawa, Czytelnik. Struve H., 1867, O emancypacyi kobiet. „Kronika Rodzinna”, nr 4, 49-53.

Sukertowa-Biedrawina E., 1965, Dawno a niedawno: wspomnienia. Olsztyn, Pojezierze. Szczęsna, 1887, Ziarnko gorczycy. „Bluszcz”, nr 3, 23.

Szwarc A., 1992, Aspiracje edukacyjne i zawodowe kobiet w środowiskach inteligencji

Królestwa Polskiego u schyłku XIX wieku. W: A. Żarnowska, A. Szwarc (red.), Kobieta i edukacja na ziemiach polskich wXIX i XX w. Zbiór studiów. T. 2, cz. 1. Warszawa, Instytut Historyczny Uniwersytetu Warszawskiego, 31-43.

Szyc A., 1904, Kobieta w pedagogice. Znaczenie i warunki pracy wychowawczej. W: Kobieta współczesna. Książka zbiorowa. Nakład tygodnika „Bluszcz”. Warszawa skł. gł. w Księgarni Gebethnera i Wolffa.

Szycówna A., 1909, Nauczanie domowe. W: J.T. Lubomirski, E. Stawiński, S. Przystański, J.K. Plebański (red.), Encyklopedya Wychowawcza. T. 7. Warszawa, skł. gł. Księg. Gebethner i Wolff.

Szycówna A., 1908, Kobieta w pedagogice. Matka. T. 7. Warszawa, skł. gł. w Księgarni Gebethnera i Wolffa.

Szycówna A., 1915, O powinnościach nauczyciela i jego kształceniu. Warszawa, Księgarnia J. Lisowskiej.

Tańska K., 1876, Pamiątka po dobrej matce. W: N. Żmichowska (red.), Dzieła Klementyny $z$ Tańskich Hoffmanowej. T. VIII, Warszawa, 310, 314.

Tatarkiewiczowie W.T., 1979, Wspomnienia. Posłowie K. Tatarkiewicz. Warszawa, Państwowy Instytut Wydawniczy.

Trentowski B., Trentowski o kobietach (Z rękopisu). „Bluszcz”, 1899, nr 8, 57-58. Tyszkówna J., 1914, Nauczycielka a wakacye. „Dziecko”, 1914, nr 7, 398.

W.H., 1895, Praca nocna i wyczerpanie mózgowe. „Przegląd Pedagogiczny”, nr 12, 181-182. Walewska C., 1914, Co robić po skończeniu pensyi. W: A. Szycówna, (red.), Dziewczę polskie. Książka zbiorowa dla dorastających panien. Warszawa, E. Wende, 55-68. Wawrzykowa-Wierciochowa D., 1975, Wysłouchowa. Opowieść biograficzna. Warszawa, Ludowa Spółdzielnia Wydawnicza.

Waydel-Dmochowska J., 1958, Dawna Warszawa. Wspomnienia. Warszawa, Państwowy Instytut Wydawniczy.

Wernic H., 1958, Przewodnik wychowania. W: R. Wroczyński (oprac.) Pedagogika pozytywizmu warszawskiego. Wrocław, Zakład Narodowy im. Ossolińskich. 
Wiercieński H., 1974, Pamiętniki. Lublin, Wydawnictwo Lubelskie.

Z pedagogiki, 1868, „Bluszcz”, nr 1, 58.

Żardecki W., 1914, Wychowawca domowy. I., „Dziecko”, z. 1, 2.

Żarnowska A., 2000, Praca zarobkowa kobiet $i$ ich aspiracje zawodowe $w$ środowisku robotniczym i inteligenckim na przełomie XIX i XX wieku. W: A. Żarnowska, A. Szwarc (red.), Kobieta i praca: wiek XIX $i$ XX : zbiór studiów. T. 6 Warszawa, „DiG”, 29-52.

\title{
THE FAIR SEX? ABOUT HOME TEACHERS IN THE KINGDOM OF POLAND IN THE NINETEENTH AND EARLY TWENTIETH CENTURY
}

\begin{abstract}
The development of the emancipation movement in the nineteenth century contributed to taking up employment by the representatives of the fair sex. Being married and having family did not satisfy women's needs and life ambitions. The editors of women's magazines addressed their expectations by providing information about potential professions in which they could find career fulfillment. Working as a home teacher was considered attractive. However, few women realized that it was a difficult profession requiring sacrifice. In a fight for the position, they competed not only with women but also with men. They had to gain the support of the employers and their families and win the favor of the students. Not infrequently, due to a large number of duties, they postponed plans to start a family or relinquished them, choosing a single life. A small group of them was able to combine work with family responsibilities.
\end{abstract}

Keywords: female home teacher, The Kingdom of Poland, gender, emancipation 